\title{
ILLEGALITY IN ENGLISH ARBITRATION LAW AFTER PATEL V MIRZA
}

\author{
Uglješa Grušić* and Manuel Penades Fons**
}

\begin{abstract}
This article examines whether the Supreme Court judgment in Patel, which recast the law of illegality in English substantive private law, is relevant for English arbitration law and, if so, what the relevance of Patel may be. We argue that Patel is indeed relevant for English arbitration law either, at least in some cases, as a matter of substance or as a matter of methodology.
\end{abstract}

Keywords: arbitration; conflict of laws; private international law; illegality; Patel v Mirza

\section{Introduction}

A pays $f 620,000$ to $B$ under a contract whereby $B$ agrees to use the money to bet on the price of shares using inside information. Insider dealing is a crime in England. The inside information fails to materialise and $B$ keeps the money. A brings a claim for restitution. These well-known facts form the factual background of Patel $v$ Mirza ${ }^{1}$ the leading case on illegality in English private law, in which the Supreme Court clarified the test to address allegations of illegality. A lot of ink has been spilt on describing and predicting the effects of Patel on various branches of substantive private law in England. ${ }^{2}$ By contrast, Patel has so far escaped scrutiny by arbitration specialists.

Arbitration law bolsters freedom of contract by allowing parties to create their own dispute resolution mechanism. An arbitration clause adds a procedural layer to a contractual relationship, which limits the ability of courts to hear disputes, including allegations of illegality, related to the contract. Returning to the abovementioned example, suppose there is an international element in the contract between $A$ and $B$, that the contract contains an arbitration clause and that $A$ has commenced arbitral proceedings. What, if any, is the relevance of Patel on these facts?

Difficulties posed by illegality are amplified in arbitration law. First, illegality can be raised either before the arbitral tribunal or a domestic court. Second, illegality can be raised before different domestic courts that exercise different supervisory and supporting functions in relation to arbitration and at different stages of the arbitral process. An English court, for example, may deal with illegality when it is asked to enforce the arbitration agreement, ${ }^{3}$ prevent the enforcement of the arbitration agreement, ${ }^{4}$ determine a preliminary point of jurisdiction ${ }^{5}$ or law, ${ }^{6}$ set aside the

\footnotetext{
* Associate Professor, Faculty of Laws, University College London.

** Lecturer in Commercial Law, King's College London.

1 [2016] UKSC 42.

2 See A Bogg and S Green (eds), Illegality after Patel v Mirza (Oxford, Hart, 2018).

${ }^{3}$ For example, by staying proceedings (Arbitration Act 1996 ('AA 1996'), s 9), appointing an arbitrator (AA 1996, s 18), filling a vacancy (AA 1996, s 27), issuing an anti-suit injunction (Senior Courts Act 1981, s 37), awarding damages for breach of the arbitration agreement (Senior Courts Act 1981, s 50) or refusing to give effect to a foreign judgment given in violation of the arbitration agreement (Civil Jurisdiction and Judgments Act 1982, s 32; see also Ecobank Transnational Inc v Tanoh [2015] EWHC 1874 (Comm) on anti-enforcement injunctions).

${ }^{4}$ For example, by issuing a declaration that the arbitration agreement is invalid, that the tribunal is not properly constituted or that the dispute falls outside the scope of the arbitration agreement and an antiarbitration injunction (AA 1996, s 72(1); Senior Courts Act, s 37).

${ }^{5}$ AA 1996, s 32.

${ }^{6}$ AA 1996, s 45.
} 
award ${ }^{7}$ or enforce the award. ${ }^{8}$ Third, an English court may deal with illegality in relation to arbitration seated in England or abroad. ${ }^{9}$ Fourth, illegality can be raised before the tribunal as an issue concerning either jurisdiction or the merits. Similarly, illegality can be raised before an English court as an issue concerning the jurisdiction of the tribunal, the merits, ${ }^{10}$ public policy ${ }^{11}$ or arbitrability. ${ }^{12}$ Fifth, the matter is further complicated by the fact that different aspects of arbitration (eg the arbitration agreement, the procedure or the merits) may be governed by different laws and that the source of alleged illegality may be yet another law. Finally, if illegality is raised before an English court as an issue of public policy at the post-award stage, the matter is even further complicated by the fact that the arbitral award adds a procedural layer of separation between the court and the illegality allegedly affecting the arbitration agreement or the underlying contract.

It, therefore, comes as no surprise that the topic of illegality in arbitration law is complex and highly controversial. We aim to contribute to the debate by examining whether the Supreme Court judgment in Patel is relevant for English arbitration law and, if so, what the relevance of Patel may be. The following section deals with the first of these two questions. After showing that Patel is relevant for English arbitration law, we turn to the Supreme Court judgment in Patel to explore what questions raised by this case and what parts of the judgment may be relevant for arbitration law. We then focus, in two separate sections, on the potential relevance of Patel to pre-award and postaward litigation brought in England. The final section concludes.

\section{The relevance of Patel for English arbitration law}

Patel concerned unjust enrichment. Commentators, however, agree that the Supreme Court judgment is relevant for English private law more generally. ${ }^{13}$ But when commentators state that the 'approach [in Patel] was clearly being put forward as applicable across civil law' ${ }^{14}$ or that 'Patel was a pivotal moment in English private law', ${ }^{15}$ they actually mean that Patel is relevant for English substantive private law, ie 'generally across tort, contract, trusts and employment law' ${ }^{16}$ Little, if any, attention has been paid to the question whether Patel is relevant for other branches of English private law such as arbitration law or private international law. As we shall see, this question has started to surface in practice.

Our argument is that Patel is indeed relevant for English arbitration law for the following reasons:

1) the clarification of the test to address allegations of illegality brought by Patel is relevant whenever English law governs the arbitration agreement or the merits;

\footnotetext{
${ }^{7}$ AA 1996, ss 31(5), 67-69, 72(2).

${ }^{8}$ AA 1996, ss 66, 100-103.

${ }^{9}$ Pursuant to AA 1996, s 2, ss 9 and 66 of the Act apply to both English and foreign arbitrations. Ss 100-103 apply to awards made in the territory of a foreign state which is a party to the New York Convention. An English court will not give effect to a foreign judgment given in violation of an arbitration agreement regardless of the seat of arbitration.

${ }^{10}$ AA 1996, ss 45, 69.

${ }^{11}$ AA 1996, ss 66, 81(1)(c), 103(3).

${ }^{12}$ AA 1996, ss 66, 81(1)(a), 103(3).

${ }^{13}$ Bogg and Green (eds) (n 2).

${ }^{14}$ A Burrows, 'A New Dawn for the Law of Illegality' in Bogg and Green (eds) (n 2) 23, 27.

$15 \mathrm{~J}$ Goudkamp, 'The Law of Illegality: Identifying the Issues' in Bogg and Green (eds) (n 2) 39, 40.

${ }^{16}$ A Bogg and S Green, 'Introduction' in Bogg and Green (eds) (n 2) 1.
} 
2) Patel, read together with a preceding Supreme Court judgment on illegality in Les Laboratoires, ${ }^{17}$ might have changed the treatment of foreign illegality under the common law of conflict of laws: courts might now be able to take into consideration illegality other than that provided by the proper law or the law of the place of performance of the contract. The treatment of foreign illegality under the common law of conflict of laws is inextricably connected with the treatment of illegality in arbitration law;

3) the methodology of analysis consecrated by Patel confirms the appropriateness of the approach traditionally adopted by English courts in arbitration-related litigation concerning allegations of illegality;

4) the reasoning in Patel might add a layer of sophistication and nuance to the approach developed by English courts specifically with respect to illegality in post-award litigation. This concerns the relevance of glosses, the use of the integrity of the legal system as a relevant factor and the possibility of applying slightly different degrees of review in setting-aside and enforcement proceedings.

These four effects have both substantive and methodological implications.

If English law governs the arbitration agreement and a party argues that the agreement is invalid, inoperative or incapable of being performed because of illegality, the existence and effects of the illegality are assessed under English law ${ }^{18}$ which includes Patel. If English law governs the merits and there is an allegation of illegality concerning the underlying contract, the test to address allegations of illegality brought by Patel applies to decide on the substantive rights and obligations of the parties. ${ }^{19}$

If English law does not govern the arbitration agreement or the merits, it is not obvious that Patel holds any relevance for English arbitration law. Our argument is that it may be relevant because Patel and Les Laboratoires have arguably affected the common law conflict of laws rules on foreign illegality, which are inextricably connected with the treatment of illegality in arbitration law. Illegality in the English private international law of contracts is now typically addressed under Article 9 of the Rome I Regulation, ${ }^{20}$ which concerns overriding mandatory provisions. Rome I, however, does not apply to arbitration because arbitration agreements are expressly excluded from its scope ${ }^{21}$ and because the addressees of the Regulation are Member State courts, not arbitral tribunals. ${ }^{22}$ This means that for the present discussion it only matters that illegality in arbitration law is inextricably connected with foreign illegality in the common law of conflict of laws.

\footnotetext{
17 Les Laboratoires Servier v Apotex Inc [2014] UKSC 55.

${ }^{18}$ Dalmia Dairy Industries v National Bank of Pakistan [1978] 2 Lloyd's Rep 223 (CA).

${ }^{19}$ The tribunal can decide whether an allegedly illegal contract is invalid or unenforceable: Harbour Assurance Co (UK) Ltd v Kansa General International Insurance Co Ltd [1993] QB 701; Westacre Investments Inc v Jugoimport SDPR Holding Co Ltd [1999] QB 740, 768-771; Fiona Trust \& Holding Corp v Privalov [2007] UKHL 40.

${ }^{20}$ Regulation (EC) No 593/2008 of the European Parliament and of the Council of 17 June 2008 on the law applicable to contractual obligations [2008] OJ L177/6. See also Art 16 of Regulation (EC) No 864/2007 of the European Parliament and of the Council of 11 July 2007 on the law applicable to non-contractual obligations [2007] OJ L199/40. Law Applicable to Contractual Obligations and Non-Contractual Obligations (Amendment etc) (EU Exit) Regulations 2019 SI 2019/834 will transpose the provisions of Rome I and Rome II into UK law after Brexit.

${ }^{21}$ Rome I, Art 1(2)(e).

${ }^{22}$ Arbitrators may resort, however, to Rome I to solve choice-of-law questions in the absence of choice by the parties.
} 
A. Patel and illegality in the common law of conflict of laws

At common law, illegality is governed by the proper law of the contract. ${ }^{23}$ There are some exceptions to this principle, the most important of which is public policy. Public policy operates in negative and positive ways. ${ }^{24}$ English courts can refuse to apply a rule on illegality of the foreign applicable law if that rule or its application are contrary to English public policy. Even if a contract is legal under its proper law, English courts can in some circumstances apply an English rule on illegality.

Another exception is laid down in cases in which English courts gave effect to foreign illegality even if the contract in question was governed by English law in which there was no equivalent illegality. An English court will not enforce an English contract to the extent to which its performance is illegal under the law of the place of performance..$^{25} \mathrm{An}$ English court will hold an English contract invalid if the real object and intention of the parties necessitates them joining in an endeavour to perform in a foreign and friendly country an act which is illegal under the law of that country, even if that act is not necessarily required by the terms of the contract. ${ }^{26}$ In cases of this kind, English courts must refuse to give effect to the contract; there is no room for discretion. ${ }^{27}$ Although the matter is controversial, the prevailing view is that these rules form part of English contract law only, and not of English private international law. ${ }^{28}$ This means that illegality in the place of performance might not be a decisive factor to render the contract invalid or unenforceable if the contract is subject to foreign law other than the law of the place of performance and it is legal under its proper law.

This rule-based approach to foreign illegality has been brought into question by the recent Supreme Court judgments in Les Laboratoires ${ }^{29}$ and Patel. Les Laboratoires concerned a claim for damages on a cross-undertaking given by the claimant that it would comply with any order that the court might make if it should later find that an interim injunction the claimant had obtained against the defendant had caused loss to the defendant. The claimant raised as a defence that the defendants' lost profits would have accrued from sales in England of a product whose manufacture in Canada would have infringed a Canadian patent. It was conceded in the Court of Appeal that the illegality defence could apply where the source of the profits from sales in England was illegal under foreign law. ${ }^{30}$ The Supreme Court omitted to discuss English cases on foreign illegality and apparently proceeded on the basis that violations of foreign laws were to be treated in the same way as violations of domestic laws for the purposes of applying English law rules founded on the maxim ex turpi causa non oritur actio. ${ }^{31}$ The Supreme Court held that the infringement of the Canadian patent did not constitute a relevant illegality ('turpitude') for the illegality defence to

\footnotetext{
${ }^{23}$ Kahler v Midland Bank Ltd [1950] AC 24 (HL); Zivnostenska Banka National Corp v Frankman [1950] AC 57 (HL); Re Helbert Wagg \& Co Ltd [1956] 1 Ch 323.

${ }^{24}$ T Hartley, 'Mandatory Rules in International Contracts: The Common Law Approach' (1997) 266 Hague Recueil 341, 350-354, 396-402.

${ }^{25}$ Ralli Bros v Cia Naviera Sota y Aznar [1920] 2 KB 287 (CA). See also Lemenda Trading Co v African Middle East Petroleum Co [1988] QB 448.

${ }^{26}$ Foster v Driscoll [1929] 1 KB 470 (CA); Regazzoni v KC Sethia (1944) Ltd [1958] AC 301 (HL).

27 Barros Mattos v MacDaniels Ltd [2004] EWHC 1188 (Ch).

${ }^{28}$ L Collins (gen ed), Dicey, Morris and Collins on the Conflict of Laws (London, Sweet \& Maxwell, 15th edn, 2012), [32-094], [32-097]-[32-103]; Ryder Industries Ltd v Chan [2015] HKCFA 32, [43] (Lord Collins).

${ }^{29}$ [2014] UKSC 55. See also Lilly Icos LLC v 8PM Chemists Ltd [2009] EWHC 1905 (Ch).

30 [2012] EWCA Civ 593, [69].

${ }^{31} \mathrm{~L}$ Collins (gen ed), Dicey, Morris and Collins on the Conflict of Laws: Fifth Supplement to the 15th edn (London, Sweet and Maxwell, 2018), [32-102].
} 
operate. Had the Supreme Court considered English cases on foreign illegality, it should have assessed whether the claim in Les Laboratoires should have been refused on the basis that Canadian law could simply not be taken into account because it was neither the proper law nor the law of the place of performance of the relevant obligations.

Since Patel did not concern foreign illegality, the Supreme Court neither approved nor disapproved this aspect of Les Laboratoires. Nevertheless, it is important to note that, whilst the majority in Patel disagreed and the minority agreed with the rule-based approach to illegality adopted in Les Laboratoires, none of the judges in Patel questioned the assumption in Les Laboratoires that the infringement of a Canadian patent would have been relevant for the illegality defence to operate had it constituted a relevant illegality ('turpitude'). We cannot draw any solid conclusions about the correctness of the omission of a conflicts analysis in Les Laboratoires from the mere fact that such omission was not questioned in Patel. But, as the editors of Dicey, Morris and Collins conclude, there may be scope to extend the flexible, policy-based approach to illegality of the majority in Patel to foreign illegality and reconsider the rule-based approach to foreign illegality of the preceding English case law. ${ }^{32}$ At most, this could entail giving English courts discretion to give effect to illegality under the law of a foreign country even if that law is not the proper law of the contract and if the place of performance of the contract is not in that country. The consequence of this happening would be a tectonic shift in the common law of conflict of laws. On the one hand, foreign illegality would become the concern of both contract law and conflict of laws. On the other hand, it would harmonise the methodological approach to illegality in English substantive law and the common law of conflicts of laws.

B. Patel, illegality in arbitration law and the common law of conflict of laws

Illegality in English arbitration law is inextricably connected with foreign illegality in the English common law of conflict of laws. In Soleimany ${ }^{33}$ and Westacre,$^{34}$ the leading cases on illegality in English arbitration law, the courts discussed illegality by reference to some of the leading cases on foreign illegality in the common law of conflict of laws. In Soleimany, the court started its discussion of the 'illegality issue' by reproducing Stuart-Smith L's summary of the law relating to illegality in Royal Boskalis Westminster NV v Mountain, ${ }^{35}$ which prominently featured Foster $v$ Drisco ${ }^{36}$ and Regazzoni. ${ }^{37}$ Westacre was largely about distinguishing Soleimany and Lemenda. ${ }^{38}$

It is for these reasons that Patel may be relevant for English arbitration law even if English law does not govern the arbitration agreement or the merits. If Les Laboratoires and Patel have affected the common law conflict of laws rules on foreign illegality, the arbitration jurisprudence based on those rules might have to be redefined.

There is only one reported post-Patel case concerning illegality in arbitration law. In Sinocore, ${ }^{39}$ the court dealt with the enforcement of a New York Convention award. The dispute arose out of a contract for the sale of goods. The seller had presented forged bills of lading. The tribunal

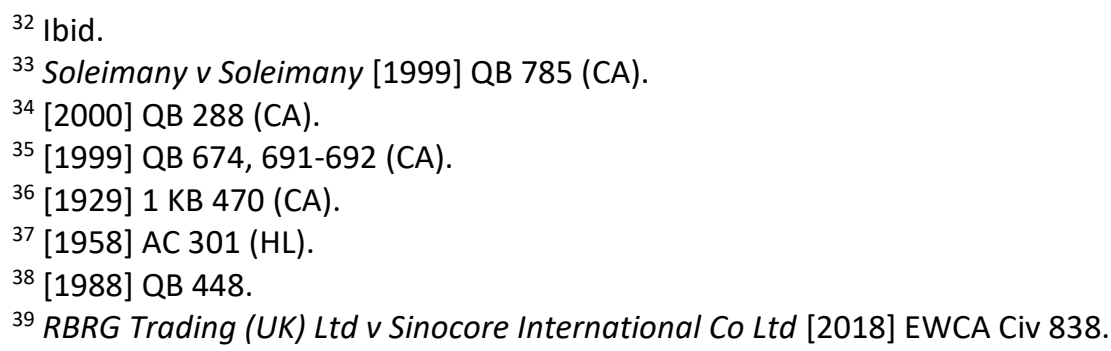


decided in favour of the seller. The High Court ordered the enforcement of the award because the contract was not unlawful or otherwise contrary to public policy and because the award, on its face, was not based on the fraudulent presentation of the forged bills. ${ }^{40} \mathrm{~A}$ basis of appeal was that the judge had applied the wrong test for assessing the consequences of the seller's illegality:

He applied the overly narrow (and now discarded) test, set out in Tinsley v Milligan [1994] 1 AC 340, of whether [the seller's] pleaded claim relied on its own fraud. He should have applied the more flexible approach laid down by the Supreme Court in Patel $v$ Mirza. ${ }^{41}$

Hamblen $L$ disagreed:

Patel $v$ Mirza does not affect the principles to be applied when considering recognition and enforcement under section 103 [of the Arbitration Act 1996]. Patel v Mirza will be relevant to whether, on the facts found, there is any illegality as a matter of English law. The policy considerations taken into account for the purpose of that determination may overlap with those to be considered under section 103, but Patel v Mirza neither purports to nor does it consider or decide the proper approach to be taken in section 103(3) cases. In particular:

(1) Prior to Patel $v$ Mirza it is clear that a distinct approach applied in the context of a challenge to enforcement of arbitration award under section 103(3), compared to the enforcement of a substantive claim.

(2) In Patel v Mirza the Supreme Court did not consider any of the authorities on illegality and public policy in the context of section 103(3). These authorities were not cited in argument, nor were they referred to in the judgment. There is nothing in the judgment to suggest that the Supreme Court contemplated that the approach it set out might also be applicable in the context of section 103(3).

(3) There are sound justifications for taking a different approach to substantive claims and enforcement claims, reflecting the different role performed by the court in each circumstance...

(4) It may be that Patel $v$ Mirza has moved the jurisprudence on illegality as a defence to a substantive claim rather closer to the multifactorial approach that has always applied in the context of illegality as a public policy defence to enforcement, but the context and the relevant factors remain different. In particular, as the authorities make clear, there is always a strong public policy in support of enforcement. ${ }^{42}$

One should not read too much into this quote. Hamblen $L$ did not say that Patel was irrelevant for arbitration law. He said that the principles to be applied when considering recognition and enforcement under section 103 had not been affected by Patel. We agree with this. Our argument is that Patel may be relevant for English arbitration law even if English law does not govern the arbitration agreement or the merits either, at least in some cases, as a matter of substance or as a matter of methodology. In order to test this hypothesis, we need to take a closer look at the Supreme Court judgment in Patel and the principles and rules applicable in pre-award and post-award litigation brought in England.

\footnotetext{
${ }^{40}$ [2017] EWHC 251 (Comm).

${ }^{41}$ [2018] EWCA Civ 838, [21](i).

$42 \mathrm{lbid},[26]$.
} 


\section{Patel: A Closer Look}

Lord Toulson's judgment in Patel, which sets out the majority's flexible, policy-based approach to illegality, is well known. Lord Toulson summarised this approach as follows:

The essential rationale of the illegality doctrine is that it would be contrary to the public interest to enforce a claim if to do so would be harmful to the integrity of the legal system (or, possibly, certain aspects of public morality...). In assessing whether the public interest would be harmed in that way, it is necessary (a) to consider the underlying purpose of the prohibition which has been transgressed and whether that purpose will be enhanced by denial of the claim, (b) to consider any other relevant public policy on which the denial of the claim may have an impact and (c) to consider whether denial of the claim would be a proportionate response to the illegality, bearing in mind that punishment is a matter for the criminal courts. Within that framework, various factors may be relevant, but it would be a mistake to suggest that the court is free to decide a case in an undisciplined way. The public interest is best served by a principled and transparent assessment of the considerations identified, rather by than the application of a formal approach capable of producing results which may appear arbitrary, unjust or disproportionate. ${ }^{43}$

Patel was allowed to enforce his claim for unjust enrichment. The fact that the money which he sought to recover was paid for an unlawful purpose did not bar the claim. Patel was not one of the 'rare cases where for some particular reason the enforcement of such a claim might be regarded as undermining the integrity of the justice system' ${ }^{\prime 4}$

Patel has been criticised despite the welcome clarification of the test to address allegations of illegality, largely because of the number of questions it left open. ${ }^{45}$ Asking some of these questions from the perspective of arbitration law helps us to inform the discussion that follows.

One question left open by Patel is whether the majority's approach to illegality, assuming that it extends across private law, superseded other rules that had been developed in specific types of case ${ }^{46}$ Assuming that Patel is of some relevance for arbitration law either directly because of the change it and Les Laboratoires have arguably made to the treatment of foreign illegality in the common law of conflict of laws or indirectly through the methodology of analysis it consecrated, this question can be rephrased as whether Patel superseded the rules laid down in Soleimany, Westacre and similar cases or whether it constitutes a 'mere crosscheck ${ }^{\prime 47}$ on those rules.

Another question left open by Patel is how the majority's approach to illegality is to be applied, in particular which factors can or should be taken into account in applying this approach and how much weight is or should be given to each factor. ${ }^{48}$ From the perspective of arbitration law, some of the relevant factors are mentioned in section 1 of the Arbitration Act 1996. Other relevant factors and the weight to be given to them have to be uncovered by looking at the relevant case law and arbitration theory.

\footnotetext{
43 [2016] UKSC 42, [120].

44 Ibid, [121].

${ }^{45}$ See Goudkamp (n 15).

${ }^{46}$ Ibid, 42-44.

${ }^{47}$ Ibid, 44.

48 Ibid, 44-48.
} 
Patel does not clarify whether the illegality doctrine is a single rule or encompasses two rules, one of which prevents liability from arising and the other of which affects only the remedy. ${ }^{49}$ The importance of this for substantive law is that 'if there are two rules...the liability rule might be controlled by one test (the "range of factors" approach enunciated in Patel) and the quantum rule by another'.$^{50}$ The importance of this for arbitration law is that the doctrine of illegality might operate differently in situations which raise the issue of validity of the arbitration agreement or the award and in situations which concern their enforcement.

It is not clear what does or should count as 'turpitude' for the purposes of Patel, ${ }^{51}$ including whether Patel affects statutory illegality..$^{52}$ From the perspective of arbitration law, it can be asked not only whether criminal conduct, 'quasi-criminal' conduct and civil wrongs count as turpitude and what relationship the turpitude must have with the claim, ${ }^{53}$ but also how the typically international character of arbitration affects the analysis of what counts as turpitude. This includes the fact that an English court may be required to deal with illegality in relation to arbitration whose seat is in England or a foreign arbitration, that different aspects of arbitration may be governed by different laws and that the source of alleged illegality may be yet another law. It can further be asked whether different approaches exist or should be adopted to different kinds of illegality. Violation of EU law and statutory illegality are obvious candidates for a separate treatment.

The following discussion addresses some of these questions from the perspective of arbitration law. It is divided in two sections concerning pre-award and post-award litigation brought in England.

\section{Pre-award Litigation}

Pre-award litigation in which illegality is raised typically concerns the validity and enforcement of the arbitration agreement. The source of the legal rules whose violation constitutes the illegality in question is crucial here.

If the source of illegality is the violation of EU law, a unique set of considerations applies. The best example is Accentuate Ltd $v$ Asigra Inc ${ }^{54}$ where the High Court refused to stay its proceedings and refer the parties to arbitration in Canada because the claim before the court was based on certain mandatory provisions of EU law origin contained in the UK implementation of the Commercial Agents Directive ${ }^{55}$ and the Canadian arbitrators had already decided the dispute by applying the law of Ontario. In cases which trigger the application of mandatory provisions of EU law, the EU public policy of the creation of the internal market prevails over conflicting public policies, including the promotion of party autonomy and arbitration. The dominance of the EU public

\footnotetext{
49 lbid, 48-49.

50 Ibid, 49.

51 lbid, 52-54.

52 Bogg and Green (n 2), 19; Burrows (n 14), 24-25; J O'Sullivan, 'Illegality and Contractual Enforcement after Patel v Mirza' in Bogg and Green (eds) (n 2) 165, 179.

${ }^{53}$ See Les Laboratoires [2014] UKSC 55.

54 [2009] EWHC 2655 (QB).

${ }^{55}$ Commercial Agents (Council Directive) Regulations SI 1993/3053, implementing Council Directive 86/653/EEC of 18 December 1986 on the coordination of the laws of the Member States relating to selfemployed commercial agents [1986] OJ L382/17. See also Case C-381/98 Ingmar GB Ltd v Eaton Leonard Technologies Ltd [2000] ECR I-9305; Case C-126/97 Eco Swiss China Time Ltd v Benetton International NV [1999] ECR I-3055.
} 
policy of market building, however, does not necessarily eliminate arbitration in cases which trigger the application of EU law. Accentuate was an unusual case in that a party applied for a stay of court proceedings under section 9 of the Arbitration Act 1996 after the arbitral proceedings had been concluded and the arbitrators had refused to apply the UK implementation of the Commercial Agents Directive. In a typical case in which a party applies for a stay of court proceedings under section 9 either before or during the arbitral proceedings, there is a way to balance competing public policies. If the tribunal has or is given a mandate by the parties to apply EU law, it would be a disproportionate interference with the public policies of promoting party autonomy and arbitration for English courts to refuse to enforce the arbitration agreement by staying proceedings under section 9. ${ }^{56}$ Even if Patel is not directly applicable to cases which trigger the application of EU law, it is worth noting that the methodology of balancing competing public policies and applying the test of proportionality is precisely the kind of methodology laid down in the majority judgment in Patel.

If the source of illegality is the violation of a statute forming part of English law, the statute may expressly or impliedly determine the effect of its violation on the validity and effectiveness of the arbitration agreement. There is nothing in Patel to suggest that it affects the process of statutory construction. ${ }^{57}$

If the source of illegality is not the violation of EU law or an English statute, an additional crucial factor becomes the law governing the arbitration agreement. If English law governs the arbitration agreement and the source of illegality is the violation of an English common law rule, the effects of the common law illegality are assessed under English law. English law includes not only the principles laid down in Patel, but also a pro-arbitration interpretation of arbitration agreements and a very strong doctrine of separability. ${ }^{58}$ If Patel applies as part of the governing English law, the tribunal and domestic courts should apply the methodology of balancing the public policy promoted by the violated English common law rule, ie the integrity of the legal system, and competing public policies $^{59}$ and the test of proportionality.

If English law governs the arbitration agreement and the source of illegality is the violation of a rule of foreign law, the following principles and rules apply. The Court of Appeal in Soleimany stated obiter that an arbitration agreement is invalid if it submits to the tribunal the question of how to split the proceeds of a joint venture that has as its object the commission of illegal acts in a foreign and friendly state.$^{60}$ This rule is the transposition into arbitration law of the common law rule that an English court will hold an English contract invalid if the real object and intention of the parties necessitates them joining in an endeavour to perform in a foreign friendly country an act which is illegal under the law of that country. ${ }^{61} \mathrm{~A}$ related common law rule on foreign illegality that has an impact on arbitral jurisdiction is that an English court will not enforce an English contract to

\footnotetext{
${ }^{56}$ Fern Computer Consultancy Ltd v Intergraph Cadworx \& Analysis Solutions Inc [2014] EWHC 2908 (Ch), [126][128]; J Kleinheisterkamp, 'Overriding Mandatory Rules in International Arbitration' (2018) 67 ICLQ 903; cf Accentuate [2009] EWHC 2655 (QB), [89].

${ }^{57}$ Bogg and Green (n 16), 19; Burrows (n 14), 24-25. O'Sullivan (n 52), 179.

${ }^{58}$ AA 1996, ss 2(5), 7; Fiona Trust [2007] UKHL 40; see also Harbour Assurance [1993] QB 701; Westacre [1999] QB 740, 755-767; National Iranian Oil Co v Crescent Petroleum Co International Itd [2016] EWHC 510 (Comm), [7]-[17].

${ }^{59}$ Competing public policies include the promotion of party autonomy and arbitration: S Brekoulakis, 'The Historical Treatment of Arbitration under English Law and the Development of the Policy Favouring Arbitration' (2019) 1 OJLS 124.

60 [1999] QB 785, 797-798 (CA). Compare Beijing Jianlong Heavy Industry Group v Golden Ocean Group Ltd [2013] EWHC 1063 (Comm).

${ }^{61}$ Foster v Driscoll [1929] 1 KB 470 (CA); Regazzoni (1944) Ltd [1958] AC 301 (HL).
} 
the extent to which its performance is illegal under the law of the place of performance. ${ }^{62}$ Transposed into arbitration law, this rule states that an English arbitration agreement will not be enforced to the extent to which it provides for an arbitration which is illegal under the law of the country where the arbitration has to be performed, ie the law of the seat of arbitration. ${ }^{63}$ The relevance of Patel in these scenarios might be the softening of the transposition into arbitration law of the common law rules on foreign illegality. In other words, Patel (read together with Les Laboratoires) would entitle the tribunal and domestic courts to apply the test of proportionality and the methodology of balancing the public policy promoted by the violated rule and competing public policies. ${ }^{64}$

If foreign law governs the arbitration agreement, the existence and effects of illegality will typically be assessed under that foreign law. ${ }^{65}$ There are some exceptions to this principle.

An exception is derived from the following statement of Waller $L$ in Soleimany:

There may be illegal or immoral dealings which are, from an English law perspective, incapable of being arbitrated because an agreement to arbitrate them would itself be illegal or contrary to public policy under English law. The English court would not recognise an agreement between the highwaymen to arbitrate their differences any more than it would recognise the original agreement to split the proceeds. ${ }^{66}$

The language used in this judgment suggests that English courts would never recognise an arbitration agreement between highwaymen, regardless of where they operated, the seat of the arbitration and the law governing the arbitration agreement. There are two ways to conceptualise the operation of this illegality. The first is to regard it as a positive operation of English public policy, ie as an overriding application of an English rule on illegality. The other is to regard it as a consequence of the application of English rules on arbitrability. Waller L's judgment is inconclusive. The quote above provides support for the second conceptualisation, ${ }^{67}$ but some other parts of the judgment provide support for the first. ${ }^{68}$

The High Court judgment in Westacre supports the second conceptualisation. ${ }^{69}$ This judgment further clarifies that courts should balance the competing policies promoted by the

${ }^{62}$ Ralli Bros [1920] 2 KB 287 (CA).

${ }^{63}$ Tamil Nadu Electricity Board v ST-CMS Electric Company Private Ltd [2007] EWHC 1713 (Comm), [46]-[49]; Abuja International Hotels Limited v Meridien SAS [2011] EWHC 87 (Comm), [27].

${ }^{64}$ In addition to the public polices mentioned in $\mathrm{n} 59$ above, the competing public policies include comity if the violated rule belongs to the law of a state which is foreign and friendly to the UK.

${ }^{65}$ Westacre [2000] QB 288 (CA); Omnium de Traitement et de Valorisation SA v Hilmarton Ltd [1999] 2 All ER (Comm) 146.

${ }^{66}[1999]$ QB 785, 797 (CA). See also 799, referring to contracts for trading with the enemy and between robbers.

${ }^{67}$ See also ibid, 799 ('it may be that in the case of palpable illegality (to use the expression adopted by Colman $J$ in Westacre Investments Inc v Jugoimport-SPDR Holding Co Ltd [1999] QB 740, 767F), an English court would declare that there was no arbitrable dispute') and 802 ('the arbitrator has no jurisdiction to make an award'). ${ }^{68}$ Waller $L$ refers, at [1999] QB 785, 797, to an arbitration agreement between highwaymen being 'void for illegality' and 'invalid' See also 799, where Waller $L J$ refers to contracts for trading with the enemy and between robbers, where the court would hold the arbitration clause 'void'.

${ }^{69}$ Westacre [1999] QB 740, 768-769: 'The approach to the question whether as a matter of English public policy an agreement to arbitrate that issue should be treated as enforceable must be determined by considerations similar to those deployed by the United States Supreme Court in the context of statutory illegality in relation to the anti-trust legislation in Mitsubishi Motors Corporation v Soler Chrysler-Plymouth Inc, 105A SCt 3346.' (Colman J). 
violated rule and sustaining international arbitration agreements when deciding whether a dispute concerning illegality is arbitrable. ${ }^{70}$ Proportionality is also relevant: consideration should be given

to the weight that ought to be attached to the risk that arbitrators might reach the wrong decision in a way which could not be challenged and thereby give effect to an underlying contract which the courts would have declined to enforce ${ }^{71}$

and 'whether the case involves consideration of complex principles of English law capable only of being safely determined by an English court'. ${ }^{72}$ This methodology of balancing competing public policies and applying the test of proportionality is precisely the kind of methodology laid down in the majority judgment in Patel.

Patel and Les Laboratiores might be seen as lending support to another exception to the principle that the existence and effects of illegality will be assessed under the foreign law governing the arbitration agreement. If foreign law governs the arbitration agreement, and a party argues that the agreement is invalid, inoperative or incapable of being performed because of the violation of a rule that belongs to another foreign law, the illegality will typically be irrelevant if the governing law attaches no relevance to it. The prevailing view is that English common law rules on foreign illegality are irrelevant in this situation because they are part of English substantive law only. ${ }^{73}$ But if Patel and Les Laboratiores have indeed affected the common law conflict of laws rules on foreign illegality, this might have had an effect on the treatment of foreign illegality in arbitration law. In other words, the rule that an arbitration agreement is invalid if it submits to the tribunal the question of how to split the proceeds of a joint venture that has as its object the commission of illegal acts in a foreign and friendly state would then apply even in cases where the arbitration agreement is governed by foreign law.

\section{Post-award Litigation}

Issues of illegality can arise in a number of ways in the context of post-award litigation. A party might challenge or resist the recognition and enforcement of the award for lack of jurisdiction. ${ }^{74}$ What has been said in the previous section about Patel and arbitral jurisdiction is also relevant in this context. Illegality can found a challenge on a point of English law. ${ }^{75}$ Patel is central to this analysis, as it establishes the approach to illegality in English private law. Finally, courts might be asked to consider issues of illegality when a party argues that the award is contrary to public policy or concerns an inarbitrable matter. ${ }^{76}$ This section focuses on the relevance of Patel for situations in which illegality is invoked under the guise of public policy.

Public policy constitutes a ground to set aside an English award and to refuse its recognition and enforcement. The relevant public policy is English public policy. In these contexts, courts are not dealing with the underlying contract, but with the award that resolves a dispute derived from that contract and the existence of illegality in the contract is just one of the relevant factors. Considerations that operate in the sphere of illegality such as the integrity of the legal system and

\footnotetext{
70 [1999] QB 740, 769.

$71 \mathrm{Ibid}$. See also 767.

72 lbid, 769.

${ }^{73} \mathrm{~N} 28$ above.

${ }^{74}$ AA 1996, ss 31(5), 66(3), 67, 72(2), 103(2).

${ }^{75}$ AA 1996, s 69.

${ }^{76}$ AA 1996, ss 68(2)(g), 81(1)(a) and (c), 103(3).
} 
comity (in cases of foreign illegality) must be balanced against considerations favouring the finality of awards, deference toward arbitrators (and, if appropriate, foreign supervisory courts) and a general policy in support of arbitration. As a result, public policy is applied only in exceptional circumstances.

In Patel, illegality was not analysed as merely one relevant factor in the balancing exercise, but occupied centre stage. One might argue then, especially in light of Sinocore, ${ }^{77}$ that Patel is irrelevant to the operation of public policy in post-award litigation where pro-arbitration considerations traditionally take centre stage. On this view, Patel would inhabit an earlier phase of the analysis, aimed at identifying the existence of illegality and its effects on the jurisdiction of the tribunal and the merits, whereas its influence would vanish in the second stage, when the existence of illegality and the policies around it would be balanced against other relevant considerations pertaining to the arbitral context. The reality, however, is that Patel cannot be confined to that first phase. By rejecting a rule-based approach and adopting a multifactorial approach, Patel unifies the method with which issues of illegality are examined in the various areas of private law, including arbitration. The resulting methodological consistency increases the coherence of English private law in the field of illegality and confirms the appropriateness of the approach traditionally adopted by English courts in arbitration-related litigation concerning allegations of illegality.

Before we proceed, we should note that, as in the context of pre-award litigation, illegality based on the violation of EU law receives a separate treatment at the post-award stage. The duty of Member States to protect the primacy of EU law and to guarantee its effectiveness reduces the room for manoeuvre allowed by the multifactorial approach. The result is that English courts might be bound to set aside and refuse the recognition and enforcement of awards that breach mandatory EU law.

The following text, therefore, focuses on the effect of illegality other than the violation of EU law on the setting-aside and recognition and enforcement proceedings in England. Subsection $A$ describes the current law. Subsection B explores substantive and methodological effects that Patel might have on the treatment of illegality at the post-award stage.

A. The flexible, policy-based approach in post-award litigation

As in English substantive private law, the balancing of competing policies in post-award litigation is unavoidably case-specific. This is not an impediment to attempting to make some general categorisations. English law makes a fundamental distinction between awards that give effect to illegality in the underlying contract and awards that are 'tainted' by illegality. Courts may scrutinise the awards falling into the first category, although the level of scrutiny depends on whether illegality is apparent from the face of the award or requires going beyond the facts determined by the arbitrators.

In Soleimany, ${ }^{78}$ the parties and the arbitrator recognised that the underlying contract was an illicit enterprise under which it was the joint intention of the parties to smuggle carpets illegally out of Iran. The arbitrator assumed jurisdiction and ordered the defendant to pay the claimant his share of the profits of the enterprise. As the award expressly noted the illegality, the court refused to enforce the award. The same treatment will be given to an award which gives effect to an illegal

\footnotetext{
77 [2018] EWCA Civ 838.

78 [1999] QB 785 (CA).
} 
practice, such as payment or recovery of a bribe, or which upholds a fraudulent claim to payment based on the presentation of documents which were admitted by the parties, or found by the tribunal, to be forgeries. ${ }^{79}$

When the finding of illegality requires going beyond the facts determined by the arbitrators, the balancing of competing policies becomes evident. If the alleged illegality refers to a narrow category of 'universally condemned activities', ${ }^{80}$ English courts will probably entertain the argument, regardless of whether or not the evidence supporting the argument was considered by the tribunal. ${ }^{81}$ If English courts find illegality of that exceptional nature, they will not enforce the award 'for it would be contrary to public policy that the arbitrator should be entitled to ignore palpable and indisputable illegality'. ${ }^{82}$ As mentioned in the previous section, this rule might be better characterised as one of arbitrability. According to the Court of Appel in Soleimany, in the case of palpable illegality there is 'no arbitrable dispute' ${ }^{83}$ and 'an arbitrator has no jurisdiction to make an award' ${ }^{84}$ When the nature of the countervailing illegality is less severe, deference towards the adjudicative function of arbitrators reduces the possibility of examining issues of illegality at the post-award stage. If the illegality question was subject to debate during the arbitration and the tribunal concluded that the conduct was legal, courts will generally uphold the resulting award ${ }^{85}$ The only exception concerns situations in which the party opposing the award is able to adduce evidence which was unavailable during the arbitration. ${ }^{86}$ In these scenarios, the court will 'have to consider whether the public policy against the enforcement of illegal contracts outweighs the countervailing public policy in support of the finality of awards' ${ }^{87}$ In none of the reported cases did the balancing exercise result in English courts interfering with the arbitrators' decision on illegality.

The second category comprises awards that are 'tainted' by illegality but do not give effect to it. The lesser level of opprobrium associated with these cases justifies the generally positive attitude of English courts toward the arbitrators' decision. For instance, in Honeywell ${ }^{88}$ and National Iranian Oil, ${ }^{89}$ the High Court ordered the enforcement of two awards notwithstanding the allegations that the underlying contracts had been induced by bribery. The reason was that whilst bribery is clearly contrary to English public policy and contracts to bribe are unenforceable, contracts which have been procured by bribes are not unenforceable but voidable. ${ }^{90}$

The same conclusion applies where illegality is not central to the claim that motivated the arbitration or to the underlying contract, even if such illegality is apparent from the face of the award. In Sinocore, ${ }^{91}$ the Court of Appeal upheld the enforcement of the award in favour of the

\footnotetext{
79 Sinocore [2017] EWHC 251 (Comm), [30], referring to National Iranian Oil [2016] EWHC 510 (Comm), [41][42].

${ }^{80}$ Westacre [2000] QB 288, 302 (Waller LJ).

${ }^{81}$ Ibid, 311 (Waller LJ), 316-317 (Mantell LJ) (CA).

82 Westacre [1999] QB 740, 767 (Colman J), confirmed in Soleimany [1999] QB 785, 803 (Waller LJ).

${ }^{83}$ Soleimany [1999] QB 785, 799 (Waller LJ).

84 Ibid, 802 (Waller LJ). See also Westacre [1999] QB 740, 768-769 (Colman J).

${ }^{85} R \vee V$ [2008] EWHC 1531 (Comm), [13]-[16].

${ }^{86}$ This also means that where a party has failed to furnish available evidence to the tribunal, estoppel will operate to prevent the reopening of the matter: Westacre [2000] QB 288, 305-310 (Waller LJ), 316 (Mantell LJ) (CA); Honeywell International Middle East Ltd v Meydan Group LLC [2014] EWHC 1344 (TCC), [89].

${ }^{87}$ Westacre [1999] QB 740, 767-768 (Colman J).

88 [2014] EWHC 1344 (TCC), [178]-[185].

${ }^{89}$ [2016] EWHC 510 (Comm), [31]-[51]. Here, the tribunal found that there was no bribery but just a failed attempt to bribe.

90 Wilson v Hurstanger Ltd [2007] EWCA Civ 299, [38] (Tuckey LJ).

91 [2018] EWCA Civ 838.
} 
seller notwithstanding the fact that the seller had forged bills of lading to obtain payment. The illegality was not taken into account because the arbitrators found that the buyer had breached the contract before the illegality occurred.

\section{B. The silent ramifications of Patel in post-award litigation}

The influence of Patel in post-award litigation is not confined to confirming the appropriateness of the multifactorial approach traditionally adopted in arbitration law. While 'the context and the relevant factors remain different' ${ }^{\prime}{ }^{92}$ it is possible to identify some aspects of Patel that could affect the scrutiny of arbitral awards by English courts in matters of illegality.

i. Enforcement proceedings $v$ annulment proceedings: a measured approach?

The first aspect of Patel that could affect the scrutiny of arbitral awards by English courts in matters of illegality concerns the potential to distinguish between enforcement proceedings and settingaside proceedings. While the illegal conduct might coincide in both scenarios, the procedural position of the party seeking to benefit from it is fundamentally different. In enforcement actions, that party requests a judicial decision ordering the other party to comply with the award, against which illegality operates as a defence. In setting-aside proceedings, the aggrieved party in the arbitration requests the court to annul the award because of illegality.

At the moment, the case law concerning illegality in post-award litigation does not disclose any difference in treatment based on the type of proceeding. There are, however, reasons to doubt this unifying logic. Success in an enforcement action translates into a positive result. The action seeks to turn the arbitral order into tangible action by the losing party at the request of the executory power of the judiciary. Conversely, success in a setting-aside action typically results in a negative outcome, a mere declaration. The award becomes a nullity and, as a matter of English law, ceases to exist and produce effects between the parties.

This fundamental distinction of concepts is not alien to the English substantive law on illegality. In Patel, Lords Toulson and Clarke distinguished between the effects that illegality could have on the validity and enforceability of a contract; ie 'whether the contract should be regarded as tainted by illegality [or] whether the relief claimed should be granted' ${ }^{93}$ Similar conceptual scission was already present in Walker $v$ Chapman,${ }^{94}$ where Lord Mansfield distinguished between a claim to overturn an illegal contract and a claim to obtain benefit. It was also supported by the Law Commission in its 2009 report, The Illegality Defence, where it concluded that the policies which underlie the illegality defence are less likely to come into play where parties are attempting to undo, rather than carry out, an illegal contract. ${ }^{95}$

This entrenched distinction in the English substantive law of illegality begs the question whether English courts should adopt a different approach to illegality in setting-aside proceedings and in enforcement proceedings. It could be the case that considerations of illegality should feature more prominently in enforcement actions, where the consequence of ignoring them is the issuance of an order requiring a party to act. In setting-aside proceedings, on the other side, the balancing

\footnotetext{
92 Ibid, [26].

93 Patel, [219] (Lord Clarke) referring to [115] (Lord Toulson).

${ }^{94}$ Walker v Chapman (1773) Lofft 342, 98 ER 684.

95 The Law Commission, 'The Illegality Defence' (Consultation Paper No 189, 2009), [4.37].
} 
test could be more inclined in favour of upholding the award (and tolerating higher levels of illegality), leaving the stricter scrutiny to an eventual enforcement stage, in England or abroad. This measured approach would be consistent with the considerations of purposiveness and proportionality required by Lord Toulson in Patel:

In assessing whether the public interest would be harmed in that way, it is necessary (a) to consider the underlying purpose of the prohibition which has been transgressed and whether that purpose will be enhanced by denial of the claim,...(c) to consider whether denial of the claim would be a proportionate response to the illegality, bearing in mind that punishment is a matter for the criminal courts. ${ }^{96}$

The suggested dichotomy would be consistent with the national origin of the definition of public policy and with the cross-border effects of annulment decisions. If, according to the prevailing interpretation of article $\mathrm{V}(1)(\mathrm{e})$ of the New York Convention, the setting-aside of an award should bar its enforceability at an international level, ${ }^{97}$ the application of national standards such as illegality to annul an award should be subject to special caution. Otherwise, a country would risk exporting its internal notions of substantive public policy and restricting the effectiveness of an award that may never be intended to be enforced in the territory of the seat. This is also the logic that underpins article IX(2) of the European Convention on International Commercial Arbitration of 1961, which excludes annulment decisions based on arbitrability and public policy from the circumstances that can be relevant under article V(1)(e) of the New York Convention. This might be one of the factors why, to the knowledge of the authors, in England there has not been any successful challenge of an award on the basis of the violation of substantive public policy.

The suggested dichotomy would not be contrary to the doctrine of comity. Enforcing an award that violates the law of a foreign and friendly state is not the same thing as merely refusing to annul such an award. In cases of enforcement, English public policy might require courts to refuse to give effect to the award in order to avoid the disregard of relevant foreign laws (like those of the country of performance). Such level of deference, however, is not required in setting-aside actions for, even if confirmed, the content of the award is not legally implemented. The element of comity in English public policy cannot be so wide as to internalise the protection of relevant foreign laws when the court is not being asked to order an act in breach of them. Ultimately, every country should be responsible for the enforcement and protection of its own public policies.

ii. The integrity of the legal system despite arbitration

The balancing exercise required by post-award litigation includes a heavy component of arbitrationfriendly considerations (finality of awards, deference toward arbitrators, promotion of London as an arbitral seat etc). These considerations eliminate the possibility of reviewing the merits of the award and shield errors of law from judicial scrutiny. In exchange, they increase the expediency, effectiveness and commerciality of arbitration as a dispute resolution mechanism. These are laudable benefits.

The result is that courts will uphold or enforce an award in some situations in which illegality would prevent them from enforcing the underlying contract. That is, arbitration operates as a procedural layer that has the potential to hinder the correct application of the law and the

\footnotetext{
${ }^{96}$ Patel, [120] (Lord Toulson). Emphasis added.

97 Yukos Capital SarL v OJSC Oil Co Rosneft [2014] EWHC 2188 (Comm), [11].
} 
achievement of the ideals of justice that give content to the illegality defence under English substantive law. Case law demonstrates that, unlike in pre-award litigation where courts give weight to the consideration that 'arbitrators might reach the wrong decision in a way which could not be challenged and thereby give effect to an underlying contract which the courts would have declined to enforce ${ }^{\prime},{ }^{98}$ at the post-award stage the fact that upholding or enforcing an award would harm the integrity of the legal system has never played a decisive role. ${ }^{99}$

Such tendency is somehow paradoxical in the context of illegality, since Lord Toulson insisted in Patel that

[t] he essential rationale of the illegality doctrine is that it would be contrary to the public interest to enforce a claim if to do so would be harmful to the integrity of the legal system (or, possibly, certain aspects of public morality...). ${ }^{100}$

This view was further reinforced by Lord Kerr, who concluded that 'the underpinning of the preservation of that integrity...is par excellence a public policy consideration' and wondered 'what is the preservation of the integrity of the legal system, if not a public policy consideration?'101

In light of these statements, one could ask whether in future decisions courts should include the integrity of the legal system as an autonomous consideration when illegality is considered in post-award litigation. ${ }^{102}$

\section{iii. The relevance of legal certainty and the risk of ossification}

Patel is finally relevant because of what it tells us about rules and glosses in the law of illegality. While adopting an essentially multifactorial approach, the increasing sophistication of English courts in their treatment of illegality at the post-award stage has led to elaborate attempts to capture the body of case law in judge-made glosses ${ }^{103}$ and doctrinal pseudo-codifications. ${ }^{104}$ While these efforts contribute to the clarity and understanding of the law and help to increase legal certainty for the benefit of parties involved in arbitration as well as arbitrators, they do not come risk-free.

In an area where the Supreme Court has expressly abandoned a rule-based approach to embrace a flexible and policy-based approach, the successive repetition and direct application of the principles distilled in those glosses and pseudo-codifications could prove dangerous. Patel reminds us of the limited, albeit unquestionably useful, role of jurisprudential distillations, and warns us of the risk of ossification, ie turning principles into rules and structured discretion into disciplined application of precedent.

For instance, it was mentioned earlier that in the absence of fresh evidence or save in exceptional circumstances, English courts will not interfere with the arbitrators' decision on illegality.

\footnotetext{
98 Westacre [1999] QB 740, 769 (Colman J).

99 The integrity of the legal system, however, was mentioned by Waller L in Soleimany [1999] QB 785, 800 and Westacre [2000] QB 288, 315-316. Recent cases have not included such references. 
Despite the use of this approach in various cases, ${ }^{105}$ it is dangerous to perceive it as a fixed rule in light of Patel. An alternative flexible approach to this issue was suggested obiter by Waller $L$ in Soleimany and later in Westacre. According to Waller $\mathrm{L}$, regardless of whether there is fresh evidence, the court should entertain the illegality argument at least to examine whether there is prima facie evidence that the award is based on an illegal contract:

In our view, an enforcement judge, if there is prima facie evidence from one side that the award is based on an illegal contract, should inquire further to some extent. Is there evidence on the other side to the contrary? Has the arbitrator expressly found that the underlying contract was not illegal? Or is it a fair inference that he did reach that conclusion? Is there anything to suggest that the arbitrator was incompetent to conduct such an inquiry? May there have been collusion or bad faith, so as to procure an award despite illegality? Arbitrations are, after all, conducted in a wide variety of situations; not just before highpowered tribunals in international trade but in many other circumstances. We do not for one moment suggest that the judge should conduct a full-scale trial of those matters in the first instance. That would create the mischief which the arbitration was designed to avoid. The judge has to decide whether it is proper to give full faith and credit to the arbitrator's award. Only if he decides at the preliminary stage that he should not take that course does he need to embark on a more elaborate inquiry into the issue of illegality. ${ }^{106}$

Mantell $\sqcup$ and Sir David Hirst in Westacre found 'some difficulty with the concept [of some kind of preliminary inquiry short of a full scale trial] and even greater concerns about its application in practice' but decided to accept the guidelines 'uncritically'. ${ }^{107}$ Notwithstanding those difficulties, Patel can be seen as providing some support for Waller L's approach.

\section{Conclusion}

Patel is one of the most important decisions of the last decade in the field of English private law, but its effects in the areas of private international law and arbitration law are very unclear. This paper has examined Patel through the lenses of arbitration law to identify possible substantive and methodological implications. The importance of the question lies in the fact that arbitration operates primarily in the field of private law and is, in and of itself, the result of freedom of contract.

The overarching conclusion is that the adoption of the factor-based approach by the Supreme Court confirms the appropriateness of the similar approach used traditionally in arbitration-related litigation to examine issues of illegality. This methodological consistency increases the coherence in the treatment given to illegality under English private law.

From a more substantive perspective, Patel (read together with Les Laboratoires) might have changed the treatment of foreign illegality under the common law of conflict of laws. Illegality other than that provided by the proper law or the law of the place of performance might now be taken into consideration. This, in turn, might have changed the approach to foreign illegality in arbitration law.

105 Westacre [1999] QB 740, 768-771, 773, 777-784 (Colman J); National Iranian Oil [2016] EWHC 510 (Comm), [46]; Sinocore [2018] EWCA Civ 838, [25(2)].

${ }^{106}$ Soleimany [1999] QB 785, 800 (CA). See also 803-804.

107 Westacre [2000] QB 288, 316-317 (CA). 
Finally, Patel might produce some specific effects in post-award litigation. It could be used to sustain the argument that the treatment of illegality in enforcement actions should be stricter than in annulment proceedings; it confirms the relevance of the integrity of the legal system as a policy aim in its own right in the treatment of illegality; and it reminds us of the need to apply caution when relying on inherited rules and glosses concerning illegality in arbitration. 